\title{
Calculation of ground-level concentrations and mapping of pollutant dispersion fields
}

\author{
Gulmira F. Keldiyarova*, and Tanzila R. Madjidova \\ Samarkand State University, Faculty of Geography and Ecology, 140104 Samarkand, Uzbekistan
}

\begin{abstract}
This article examines the impact of building materials manufacturing on public health and the environment. It is noted that the assessment processes were carried out on the basis of modern software and the analysis of the width of the atmospheric emissions of harmful substances emitted by enterprises. In addition, the use of normative documents, the accounting of the sources of emissions are recorded. And also, the rules for the field of dispersion of pollutants in the surface layer of the atmosphere are given.
\end{abstract}

\section{Introduction.}

The emissions of enterprises of various industries and transport contain a large number of different harmful impurities. Over the past decade, serious practical steps have been taken that would significantly change the attitude of the human community to nature, to the problem of its conservation, in order to ensure the sustainable development of future generations. The bank of unresolved environmental problems continued to increase. There are many reasons for this, and not the least of them is the low professionalism of professionals who make decisions in the field of environmental protection, in the field of its protection from industrial waste.

This fully applies to the problem of protecting atmospheric air from dust-gaseous emissions. The object under consideration of LLC "Samarkand Uzbekgazsuv Kurilish" with the existing asphalt concrete plants is located in the industrial zone of the city of Jambay, Jambay district, on its own territory. The nearest localities are: Djambay remote East at 70 $\mathrm{m}$ and Hasdal remote village in the South by $300 \mathrm{~m}$. the wind rose is directed in such a way that pollutants will be directed away from residential buildings, i.e. to the west. $280 \mathrm{~m}$ from the site from the south there is a railway, followed by a local road. From the east, $300 \mathrm{~m}$ away, there is also a road leading to the city center. The M-39 highway runs from the northeast to the south-west at $530 \mathrm{~m}$.

The object is located on the right bank of the Zerafshan River, in the central part of the Zerafshan valley at an altitude of $650-750 \mathrm{~m}$ on a vast plain with a general slope from the south-east and south to the north-west and north. In $140-150 \mathrm{~km}$ to the west of the Zerafshan Valley, it greatly expands and in this area is directly adjacent to the Kyzylkum desert. From the south, the valley is bordered by the mountains Chakyl Kalyan, Karate and Ziyatdin-Zirabulak, the absolute heights of which reach $2200-2500 \mathrm{~m}$, to the west the

\footnotetext{
* Corresponding author: guli d@,inbox.ru
} 
mountains fall. From the north, the valley is bounded by the Nurata Mountains, the average height of which reaches 1400-1700m. [1]

\section{Methods}

To calculate the dispersion of pollutants into the atmosphere, in addition to the parameters of the emission sources, the following initial data are required:

* climatic and meteorological characteristics and coefficients that determine the conditions for the dispersion of pollutants in the atmospheric air in the area of the enterprise location.

* data on the coefficient that takes into account the sedimentation rate of impurities; * coefficient of relief.

Meteorological characteristics are taken according to the data of the nearest weather station to the enterprise. [2]

The aim of the research is to reduce the excessive pollution of the atmosphere by pollutants and dust emitted from sources in industrial, construction and other manufacturing enterprises in industrialized areas. It is important to analyze and scientifically substantiate them in modern computer programs based on the state of the environment in which enterprises operate. Scientific novelty is the impact of industrial enterprises on the atmosphere and cases of excessive pollution studied in Samarkand region and in a particular region. In addition, the scope of impact of enterprises on the environment has been implemented on the basis of today's modern projects. $[3,4]$

As part of this study, the laboratory of microclimate and environmental protection of Samarkand State Institute of Architecture and Construction analyzes pollutants in the atmosphere based on long-term data on water, soil and atmospheric air. For the first time, a comprehensive analysis of dust and other pollutants emitted into the environment by industrial and industrial enterprises is carried out. [5]

The method of laboratory and computational analysis is used in the new and modern program "Ecologist". This method provides specific results for calculating the dispersion of pollutants in the atmospheric air.

\section{Analyses and calculations}

The area where the ABZ site is located has an agricultural and industrial orientation of management, where along with agricultural branches - cotton growing, there are enterprises of the construction industry. From the north, $70 \mathrm{~m}$ from the enterprise under consideration, there is a flour mill, from the sources of emissions, the flour mill will be $265 \mathrm{~m}$. The wind rose is directed in such a way that the pollutants will be directed to the west. [6]

Source-boiler room. The release occurs during the combustion of natural gas in the boiler room, where one boiler of the E-1/9 brand is installed. The annual gas consumption is 66.0 thousand $\mathrm{m} 3$ / year. The calculation of pollutants generated during gas combustion was carried out according to the methodology (Instructions for conducting an inventory of pollution sources and normalizing emissions of pollutants into the atmosphere for enterprises of the Republic of Uzbekistan. 3 January 2006, No. 1553).

The gross emission of nitrogen oxides released into the atmosphere is calculated by the formula:

$$
\mathrm{M}_{\mathrm{NOx}}=0,001 * \mathrm{~B}^{*} \mathrm{Q}_{\mathrm{H}}{ }^{\mathrm{P}} * \mathrm{~K}_{\mathrm{NO} 2} *(1-\beta), \mathrm{T} / \Gamma
$$

B-fuel consumption, 66.0 thousand $\mathrm{m} 3$ / year.

$\mathrm{K}_{\mathrm{NO} 2}$-a parameter that characterizes the amount of nitrogen oxides formed per $1 \mathrm{GJ}$ of heat, $\mathrm{kg} / \mathrm{GJ}(0.075$ for plants with a capacity of $12.5 \mathrm{t} / \mathrm{h}$. 
$\beta$ is a coefficient that takes into account the degree of reduction in nitrogen oxide emissions as a result of the use of technical solutions. In the absence of technical solutions, $\beta=0$. Q HP-heat of combustion of fuel, $34,564 \mathrm{MJ} / \mathrm{m}^{3}$. The maximum single emission is calculated according to the formula (Instructions for conducting an inventory of sources of pollution and normalizing emissions of pollutants into the atmosphere for enterprises of the Republic of Uzbekistan. 3 January 2006 No. 1553):

$$
\mathrm{G}_{\mathrm{NO} 2}=\mathrm{M}_{\mathrm{NO} 2} * 10^{6} / 3600 * \mathrm{t},
$$

where, $t$ is the operating time of the equipment per year.

Gross emissions are: nitrogen oxides- $0,001 * 66,0 * 34,564 * 0,075 *(1-0)=0,171 \mathrm{t} / \mathrm{g}$ nitrogen dioxide $-0.171 * 0.8=0.137 \mathrm{t} / \mathrm{g}$.

Nitrogen oxides- $0.171 * 0.13=0.022 \mathrm{t} / \mathrm{g}$.

The maximum emissions are: nitrogen dioxide- $(0,137 * 106) /(3600 * 1440)=0,026 \mathrm{~g} / \mathrm{s}$. Nitric oxide- $(0,022 * 106) /(3600 * 1440)=0,0043 \mathrm{~g} / \mathrm{s}$.

Table 1. General data on approximate calculations of emissions of pollutants into the atmosphere of the area where the structure is located

\begin{tabular}{|c|c|c|c|c|c|c|}
\hline № & $\begin{array}{c}\text { Name of the } \\
\text { company }\end{array}$ & $\begin{array}{c}\text { MPC, a. } \\
\mathbf{d ~ m g / \mathbf { m } ^ { 3 }}\end{array}$ & $\begin{array}{c}\text { Hazard } \\
\text { class }\end{array}$ & $\begin{array}{c}\text { Number } \\
\text { of sources }\end{array}$ & Quota & $\begin{array}{c}\text { Actual } \\
\text { discharge } \\
\mathbf{m g} / \mathbf{m}^{\mathbf{3}}\end{array}$ \\
\hline 1 & Hydrocarbons & 1,0 & 4 & 2 & 0,33 & 0,034 \\
\hline 2 & Nitrogen dioxide & 0,085 & 2 & 2 & 0,20 & 0,23 \\
\hline 3 & Nitric oxide & 0,6 & 3 & 2 & 0,25 & 0.019 \\
\hline 4 & Sulfur dioxide & 0,5 & 3 & 2 & 0.33 & 0,0066 \\
\hline 5 & Carbon monoxide & 5,0 & 4 & 2 & 0,5 & 0,017 \\
\hline
\end{tabular}

It was determined that the harmful substances emitted from the asphalt concrete plant did not exceed the permissible limit based on the results of the analysis.

The calculation of the concentrations of pollutants in the atmospheric air was carried out according to the "Ecologist" program. The initial data was taken from the parameters of the emission sources. Meteorological characteristics and coefficients that determine the degree of dispersion of chemicals into the atmosphere.

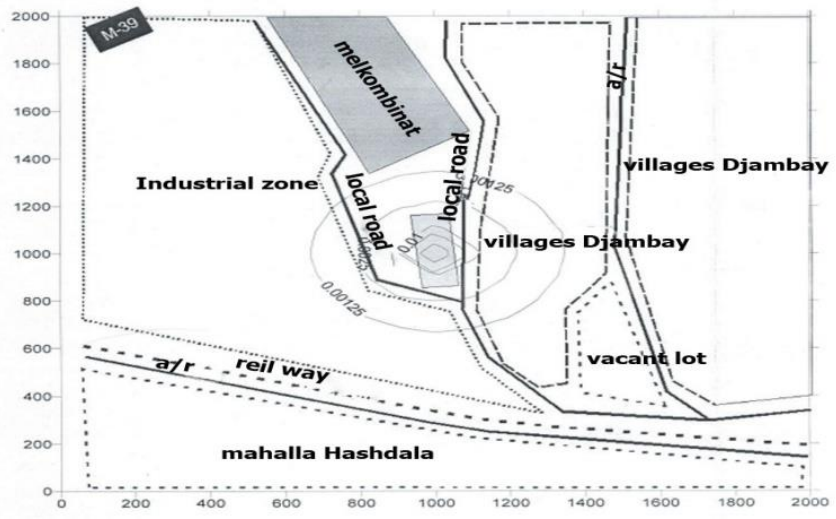

Fig. 2. Nitric oxide. 


\section{Discussion}

The calculation of the dispersion of pollutants is carried out outside the industrial site, in the fractions of the MPC (average-daily) for the atmospheric air of settlements. The map of the fields of pollutant dispersion in the atmospheric surface layer must contain the numbers of maximum concentrations in fractions MPC (average-daily). in the nodes of the computational grid and clearly marked boundary of the industrial site. [7]

The environmental impact assessment of the bitumen storage facility of LLC "Samarkand Uzbekgazsuv Kurilish" in the Jambai district showed that the area of the object location is classified as a moderate pollution zone in terms of the degree of pollution of atmospheric air, soil and groundwater, and soil and vegetation cover. The activity of the facility is the reception, storage and heating of bitumen. The annual turnover of bitumen is 4,200 tons per year.

According to the calculated data, the following level of atmospheric air pollution was determined outside the industrial site of the enterprise:

hydrocarbons- 0.034 at the established quota, 0.33 maximum permissible concentration (MPC);

nitrogen dioxide- $0.23 \mathrm{mg} / \mathrm{m}^{3} \mathrm{MPC}$ at the established quota, $0.20 \mathrm{mg} / \mathrm{m}^{3} \mathrm{MPC}$;

nitric oxide- $0.019 \mathrm{mg} / \mathrm{m}^{3} \mathrm{MPC}$ at the established quota, $0.25 \mathrm{mg} / \mathrm{m}^{3} \mathrm{MPC}$;

sulfur dioxide $-0.0066 \mathrm{mg} / \mathrm{m}^{3} \mathrm{MPC}$ at the established quota, $0.33 \mathrm{mg} / \mathrm{m}^{3} \mathrm{MPC}$;

carbon monoxide- $0.017 \mathrm{mg} / \mathrm{m}^{3} \mathrm{MPC}$ at the established quota, $0.5 \mathrm{mg} / \mathrm{m}^{3} \mathrm{MPC}$;

It should be noted that in this study for the first time in industrial enterprises of the area under consideration, the influence of harmful substances in the atmospheric air completed with new and modern projects using the method of laboratory analysis. Previously, the analysis and assessment of the impact of pollutants on the environment were carried out by the calculation and analytical method many times, and the method of laboratory analysis was carried out very rarely and the calculations were done according to the "Rainbow" program. The method of laboratory analysis in the new and modern project "Ecologist" shows the dispersion of pollutants very specifically. Differential experimental schemes showed a difference in the analysis calculations (Table 2). The difference of the nitrogen dioxide analysis is $9 \%$.

Table 2. Sampling methods and differential experimental schemes of emissions of harmful substances from the source.

\begin{tabular}{|c|c|c|c|c|c|c|c|}
\hline $\begin{array}{lr}\text { Production } & \text { facility } \\
\text { and type } & \text { of } \\
\text { installation } & \text { (nitrogen } \\
\text { dioxide) } & \end{array}$ & 兽 & 家 & 告 & 它 & 焉 & 萬 & 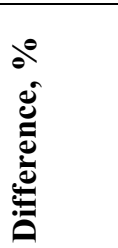 \\
\hline \multicolumn{4}{|c|}{ Method: Experiment, laboratory } & \multicolumn{4}{|c|}{$\begin{array}{l}\text { Method: computational and } \\
\text { analytical }\end{array}$} \\
\hline $\begin{array}{lr}\text { Asphalt } & \text { concrete } \\
\text { production, } & \text { zyklon } \\
\text { TSN -11 } & \\
\end{array}$ & 0,23 & 0,014 & 0,743 & 0,21 & 0,012 & 0,741 & $8,7-9 \%$ \\
\hline
\end{tabular}

\section{Conclusion}

For the first time at the industrial enterprises of the considered area the influence of harmful substances in the atmospheric air was carried out by a new and modern method with the use 
of laboratory analysis. As a result it was found that for all harmful impurities, the content of harmful substances abroad, the enterprises don't not exceed the quotas established for them. The enterprises of LLC "Samarkand Uzbekgazsuv Kurilish" does not affect the higher concentration on the environment, mainly in the atmospheric air polluting chemicals, the concentrations of which will not exceed the established quotas, and therefore can not affect the environmental situation of the area.

\section{References}

1. G. F. Keldiyarova. Int. J. Appl. Res., 5(7S), 65-67 (2019)

2. S. M. Boboev, G. F. Keldiyarova, Allocation of harmful substances from brick factories located in the Samarkand region (2018)

3. I. Yu. Popovich, I. L. Revutskaya, The impact of road transport on the quality of atmospheric air in Birobidzhan (2018)

4. A. Khaustov, M. Redina, P, Silaeva, Zh. Kenzhin, R. Mamadzhanov, International Multidisciplinary Scientific GeoConference Surveying Geology and Mining Ecology Management, SGEM, 19(4.2), 319-324 (2019)

5. V. F. Maksimov, I. V. Wolf, Cleaning and recovery of industrial emissions (Forest industry, Moscow, 1981)

6. M. I. Birger, A. Yu. Walberg, B. I. Myagkov, A. A. Rusanov, Handbook of dust and ash collection (Energoatomizdat, Moscow, 1983)

7. V. Leiti, Definitions of air pollution in the atmosphere and on the desktop (Chemistry, Leningrad, 1999) 


\section{Маджидова Танзила Рахимовна ${ }^{1}$ \\ Келдиярова Гулмира Фархадовна \\ ПРОВЕДЕНИЕ РАСЧЕТОВ ПРИЗЕМНЫХ \\ КОНЦЕНТРАЦИЙ И КАРТА ПОЛЕЙ РАССЕИВАНИЯ \\ ЗАГРЯЗНЯЮЩИХ ВЕЩЕСТВ}

${ }^{1}$ Доиент, Самаркандский государственный университет, факультет География и экология.

${ }^{2}$ Докторант (PhD), Самаркандский государственный университет, факультет География и экология.

guli_d@mail.ru

В данной статье описываются подготовки исходных данных для проведения расчетов приземных концентраций загрязняющих веществ, применение материалов инвентаризации. Расчет рассеивания загрязняющих веществ в атмосферу по универсальным программам. А также, приведена правила поле рассеивания загрязияющих веществ в приземном слое атмосферы. 